\title{
The Acculturation of Kentrung "Tri Setyo Budoyo" in Dayu Village, Nglegok District, Blitar Regency: The Theoretical Study of Cultural Change
}

\author{
${ }^{\otimes}$ Nurisa Widikurnia \\ Universitas Negeri Surabaya, Indonesia \\ Received: December 13, 2017. Revised: April 23, 2018. Accepted: June 10, 2018
}

\begin{abstract}
Kentrung "Tri Setyo Budoyo" is a traditional performing art of Blitar. That is a traditional performing art that can survive in the modern era. One of the factors affecting Kentrung "Tri Setyo Budoyo" to survive is adult acculturation on the performing arts. This article aims to (1) Describe the acculturation of art of Kentrungt "Tri Setyo Budoyo" in Dayu Village, Nglegok District, Blitar Regency. (2) Explains the innovation of Kentrung art "Tri Setyo Budoyo" in Dayu Village, Nglegok District, Blitar Regency. This research is a qualitative research, with the object of research is the art of Reog Bulkiyo in Kemloko Village, Nglegok District, Blitar Regency. Data collection techniques used through observation, interviews and documentation. Data analysis technique used is taxonomic analysis. The results showed that cultural change is universal. If there is a change in the culture of a society, it will affect other aspects such as language, knowledge system, social organization, living equipment system and technology, living livelihood system, religious system, and arts. Art Kentrung Tri Sansoso Budoyo "experiencing acculturation and renewal or innovation, this happens because the culture in the community around the environment also experience acculturation. In the art that has an open mind, it will be able to get and go through these cultural changes so as to survive and thrive in the midst of changing times.
\end{abstract}

Keywords: Acculturation; Kentrung Tri Setyo Budoyo; Cultural change

How to Cite: Widikurnia, N. (2018). The Acculturation of Kentrung "Tri Setyo Budoyo" in Dayu Village, Nglegok District, Blitar Regency: The Theoretical Study of Cultural Change. Harmonia: Journal of Arts Research And Education, 18(1), 62-66. doi:http:/ /dx.doi.org/10.15294/harmonia.v18i1.13971

\section{INTRODUCTION}

Changes and dynamics are parts of the intrinsic character in society and culture. Change is a phenomenon that occurs together with historical events of every societies and cultures. However, any changes has two possibilities whether it will bring such positive vibes or the other way around. There are so many ways to keep improving the values and also the other aspects of culture based on the development of information technology, media, and science.

Syani explained that "change means a process that cause a differentiation between the current situation and the past. The changes could emerge as a deterioration or a progression". Every society surely experience gradual changes either in a general or more specific sense and either they move quickly or slowly (evolution) (1995: 83).

The principle of changes among society, either social or cultural change, is a

\footnotetext{
${ }^{\square}$ Corresponding author: Jl. Ketintang, Gayungan, Surabaya, Jawa Timur 60231

E-mail: acanurisa@gmail.com
} 
continuous process in order to build a developed society. According to Davis (in Soejono Soekanto tth:263-267) "social change is a part of cultural change which includes the whole aspects such as art performance, science, technology, philosophy and so on".

Social cultural change is an indication of the structural change on one society's culture. This change is a general phenomenon that occurs in people's lifetime. People always adapt to the condition where they belong. They also have the consequence to synchronize both their internal and external relationship based on the society demand which also always change.

A cultural change of a society would also give certain effect on the society's art performance. Art is one of the elements of culture. In line with Kontjaraningrat's statement that there are seven elements of culture that could be found around the world. They are (1) language, (2) knowledge, (3) social organization, (4) technology, (5) system of livelihood, (6) religion, (7) arts (1990:203).

Art is one of cultural aspects that is very important to be studied further. At least people in their personal development should be aware of the importance of understanding art. A life without understanding art is a boring life and could cause a narrow minded generation toward art itself. Kentrung is an art performance from Java which combine the art of voices and music. It is a narrative art performance that accompanied by musical instrument such as tabuh timlung (kentheng) and terbang besar (rebana). This traditional art always has certain message for the audience or even the society on every performance. Therefore, as one of the art performances, this traditional performances always examine the current values in society then delivered the message in the form of art performance whether it deals with politic, morality, social or other issues (Sujarno,dkk.2003:47). The history of Kentrung actually existed in the era of Japanese. At that time Kentrung did not use kendang (traditional tambour) on its show. The characters played in Kentrung were about the prophet, moslem guardian (wali) and Indonesian kingdom. So, it is clear that Kentrung is one kind of Islamic art performance. Summeh (76) is an artist of art performance Kentrung from Blitar. Around 1993-1994 he initiated studying Kentrung and develop it with his own version of creativity. He also build Kentrung "Tri Santoso Budoyo".

Kentrung "Tri Santoso Budoyo" is played by four persons and one additional person as Sinden (traditional singer) if needed. Every persons plays music instrument such as kendang, terbang, small kendang and tipung. The characters played in Kentrung "Tri Santoso Budoyo" are mostly about folklore, legend of certain past event and the story of prophet. These characters will be played by request. The host will determine which character that will be played. According to Summeh (76), the popular character played was Jaka Tingkir. Kentrung itself contains local wisdom that represented in the performance. During the show, an artist narrates the story in order using sequence of parikan and puts in several jokes. The rhytmic parikan is sung accompanied by the play of two rebanas.

Summeh (76) Kentrung is original from Sanan, Dayu Village, Nglegok District, Blitar Regency. Blitar is one of regions that become home of kentrung development. There used to many kinds of kentrung developed in Blitar, but now only Summeh (76) kentrung that is able to keep its existence. One of many factors that make kentrung "Tri Santoso Budoyo" still survive is that it has inovation. The artists of kentrung "Tri Santoso Budoyo" are able to adapt to the current situation and current demand. It deals with the value of entertainment aspect of art performance itself. In spite of its sacred Islamic value, kentrung is able to maintain the value of entertainment so it can fulfil the demand from society as an art performance.

Now musical instrument used in kentrung "Tri Santoso Budoyo" are not only kendang, terbang, small kendang and tipung. Modern musical instrument also used in kentrung "Tri Santoso Budoyo". The modern musical instrumens are keyboard, guitar, bass and a set of drum. This form of innovation is believed as one of kentrung "Tri Santoso Budoyo" powers in order to survive in the society until now. From that phenomenon we could say 
that kentrung "Tri Santoso Budoyo" has been experiencing acculturation.

Therefore, this article will examine, identify and study further the change towards kentrung "Tri Santoso Budoyo" in Dayu village, Nglegok district, Blitar regency using theory of change and concept of acculturation process as the clue. This article will also discuss the process of acculturation occurred in kentrung "Tri Santoso Budoyo" art performance in Dayu village, Nglegok district, Blitar regency.

\section{METHOD}

This study is using qualitative research method since the main concern is to search, figure out and explain the indications and relations between every aspects of acculturation process in kentrung "Tri Santoso Budoyo" in Dayu village, Nglegok district, Blitar regency. So the data used in this study will be based on the actual situation of the object without any manipulation or another intervention from researcher.

The object of this study is kentrung "Tri Santoso Budoyo" in Dayu village, Nglegok district, Blitar regency. The data were collected using observation, interview and documentation technique.

Validity is the degree of accuracy between the data that occurs on the object of research with data reported by researchers (Sugiyono, 2015:363). This study uses the validity of data with triangulation data to obtain valid data, then the researcher did: source triangulation, and triangulation method.

The analytical technique used in this study is qualitative analysis. This study uses Spradly taxonomy analysis (in Sugiyono, 2012: 225) to obtain general image of the social situation of the research object. Taxonomy analysis is the analysis towards the whole collected data based on determined domains. The domains were arranged based on the statement of problems.

\section{RESULT AND DISCUSSION}

Acculturation to the of Kentrung "Tri Santoso Budoyo" in Dayu Village, Ng- legok District, Blitar Regency

Kentrung "Tri Santoso Budoyo" in the Village District Dayu Nglegok Blitar is a traditional art. An art of performances in the staging consists of 4 players and 1 person as sinden when needed, Each holding a musical instrument in the form of drums, flying, small kendang and tipung. Since its founding in 1993-1994 the art still survive until 2015 with the fourth instrument. Over the course of Kesenian Kentrung "Tri Santoso Budoyo" was confronted with the growing society. When people can enjoy other forms of art such as music shows on tv, comedy to tv dramas, kentrung art is considered ancient and considered to lack entertainment values.

Artist Kentrung "Tri Santoso Budoyo" is an art lover who has openness to new culture. The artists have a noble purpose, namely that the art of kentrung not disappear eroded by the arts carried by the new cultures. In the year 2015 the artists Kentrung "Tri Santoso Budoyo" then began to incorporate elements of modern music in its presentation. Modern musical instruments are musical instruments that have gained a touch of technology in the making. In contrast to traditional musical instruments that are made manually with natural materials, in modern musical instruments and manufacturing techniques are getting more recent. Modern musical instruments continue to grow and produce some modern musical streams like Rock, Pop, Jazz. Musical instruments that can then be included in the presentation of Art Kentrung "Tri Santoso Budoyo" is the bass, guitar, keyboard and drum set. By not eliminating the main elements in the form of drums, flying, small kendang and tipung and the art of speech that nuanced Islam. Art Kentrung "Tri Santoso Budoyo" at this time can develop following the cultural change of society. This is in line with the concept of acculturation that Koentjaraningrat discloses, that: acculturation is a social process arising in which a group of people with a particular culture they have are faced with elements of a foreign culture. So that foreign culture will gradually be accepted / impregnated and processed into its own culture without causing the loss of the original cultural elements 
of the group itself (Koentjaraningrat, 1990: 248).

Kentrung "Tri Setyo Budoyo" currently can be said to have been able to face the current development of the times. Incorporate new cultural elements by not abandoning the original essence of the art. Despite having a new formation on its presentation form, but artist Kentrung "Tri Setyo Budoyo" who wants to showcase the art can choose (request) to look at new formations or original formations. In this way, symbiotic mutualism between artists and art lovers of "Tri Setyo Budoyo", both of which share a common goal, is to preserve the arts of "Kentrung Tri Setyo Budoyo".

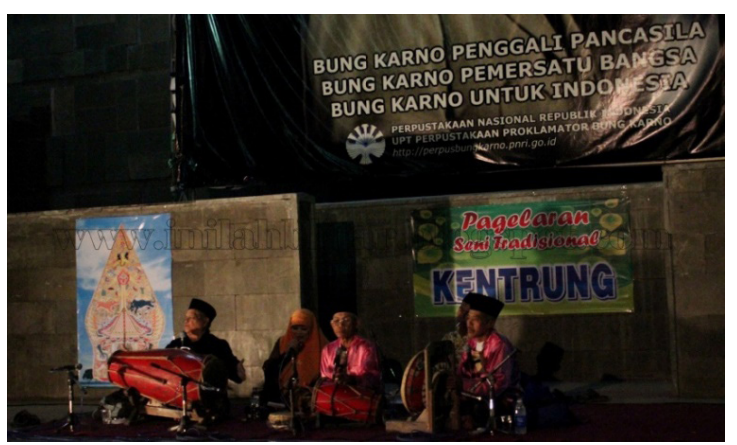

Figure 1. Kentrung "Tri Santoso Budoyo"

Renewal (Innovation) of Kentrung "Tri Santoso Budoyo" in the Village Dayu District Nglegok Blitar

Innovation or renewal is a process of renewal of the use of natural resources, energy, new arrangements of labor and the use of new technologies which will all lead to a system of production and cultural renewal especially regarding technological and economic elements. (Koentjaraningrat, 1990: 258). The renewal of Kentrung "Tri Santoso Budoyo" is in the use of musical instruments. Music is an important part in art kentrung, because as an illustration of a story. The definition of music according to KBBI is the science or art of composing tones or sounds in sequences, combinations, and temporal relationships to produce a composition (sound) that has unity and continuity (tt: 3241). Art Kentrung "Tri Santoso Budoyo" in the Village Dayu District Nglegok Blitar add modern musical instruments in the form of bass, guitar, keyboard and drum set. The update has a primary mission so that Art Kentrung "Tri Santoso Budoyo" can adapt to the development of culture. Cultural developments also influence the taste of community entertainment. The community began to be introduced to a new culture that is more able to attract people's attention, which is feared from the phenomenon is that people can forget or abandon the existing culture. Therefore, Artist Kentrung "Tri Setyo Budoyo" made an update to the instrument used.

Another thing that becomes the driving force in the renewal of the musical presentation of Kentrung art "Tri Santoso Budoyo" is the encouragement of (1) awareness of the artist that there should be an improvement for the sustainability of Kentrung Art Tri Setyo Budoyo, (2) the quality or quality modern music artists who deserve to be developed talent (3) the stimulation of the community environment to provide a new entertainment but still berpakem on kentrung art.

The awareness of artists about the importance of renewal of Artistry "Kentrung Tri Setyo Budoyo" is something that deserves high appreciation. This is because, not all original artists of an art (who are notaben to have old age) can have an open mind towards a new culture. With the openness to new culture, able to use power as one of art enhancer "Kentrung Tri Setyo Budoyo" to continue to live in modern era like nowadays, even can grow more advanced.

Community support is very important for the artistry of "Kentrung Tri Setyo Budoyo". If the support community has a high spirit to generate arts, then artists will be more motivated to struggle in preserving Art "Kentrung Tri Setyo Budoyo".

Textually, the art of Kentrung "Tri Santoso Budoyo" has not changed significantly. However, only the updates are expected to be accepted by the community. The existence of such renewal in addition to the development of the times, also influenced by society. The influence of society is in the form of stimulus or stimulus which is translated as idea by art artist Kentrung "Tri Setyo Budoyo". The idea is an opinion that Kentrung art "Tri Setyo Budoyo" is able to show appropriate 
entertainment by cultural development. In other words, the people of Dayu Village have their own concept in evaluating an entertainment. Because of having the same culture, the majority of Dayu Village residents have the same view of an object of entertainment. This is in accordance with what is expressed by (Sudikan, 2000: 11) that cultural change is a change that takes place within the system of ideas shared with a number of concerned citizens, including the rules or norms used as guidelines in the lives of citizens, the technological values of slera sense of beauty or art and language.

\section{CONCLUSION}

Cultural change is a universal matter. If there is a change on society's culture, so it will give effect the other aspects such as language, knowledge, social organization, technology, system of livelihood, religion, and arts. Kentrung "Tri Santoso Budoyo" art performance has been experiencing acculturation, improvement or innvation. This phenomenon occurs because the society where kentrung "Tri Santoso Budoyo" belong is also experiencing acculturation. The art performance that has more possibilities of innovation will also has more possibilities to survive and keep developing in the midst of changing era.

However, it will be great if those acculturated art performance still keep their original identity as traditional art performance. This is one of the efforts to keep the local wisdom, so a traditional art performance will has a strong character that cannot be erased by the cultural change.

\section{REFERENCES}

Dewan Redaksi Ensiklopedia Sastra. 2007. Ensiklopedia Sastra Indonesia. Bandung: Titian Ilmu

Hutomo, Suripan Hadi (Editor). 1993. Pantun Kentrung. Jakarta: Yayasan Obor Indonesia

Iriaji. (2015). The Meaning, Value, And Symbol Transformation As A Phenomenon
In Pottery Culture At "Kriya Nusantara" Art Studio dalam proceeding 4th International Seminar of Nusantara Heritage, UPSI, Malaysia.

Kontjaraningrat. (1990). Pengantar Ilmu Antropologi. Jakarta: PT Rineka Cipta

Kontjaraningrat. 1990. Pengantar Ilmu Antropologi. Jakarta: PT Rineka Cipta

Martono, Nanang. (2011). Sosiologi Perubahan Sosial: Perspektif, Klaksik, Modern, Posmodern dan Poskolonial. Jakarta: PT Raja Grafindo Persada

Monroe. Tanpa tahun. Kamus Besar Bahasa Indonesia Lengkap. Surabaya: Gresindo Press Persada, Jakarta

Soedarsono, Sugiyono. (2010). Metode Penelitian Pendidikan (Penelitian Kuantitatif, Kualitatif, dan R \& D). Bandung: Alfabeta

Soekanto, Soerjono. , 2006. Sosiologi Suatu Pengantar, PT. Raja Grafindo

Sudikan, Setya Yuana. (2000). Metode Penelitian Kebudayaan. Surabaya: Unipress Unesa bekerjasama dengan Citra Wicaksana.

Sudikan, Setya Yuana. 2000. MetodePenelitian Kebudayaan. Surabaya: Unipress Unesa bekerjasama dengan Citra Wicaksana

Sujarno, dkk.2003.Seni Pertunjukan Tradisional, Nilai, Fungsi Dan Tantangannya.Yogyakarta : Kementreian Kebudayaan dan Pariwisata.

Syani, Abdul. 1995. Sosiologi Dan Perubahan Masyarakat. Jakarta: PT Pustaka Jaya

Triyono Bramantyo, Susan Hung. (22017). The Javanese Panji Story: its transformation and dissemination into the performing arts in Southeast Asia. Harmonia: Journal of Arts Research and Education, 17 (2) (2017), 113-119

Tudor, A. (1999). Theory and Method in Cultural Studies. California: SAGE Publications Inc 